\title{
The Effect of Glyphosate on Human Sperm: In Vitro Approximation
}

\section{Efecto del glifosato sobre los espermatozoides humanos: una aproximación in vitro}

\author{
Mateo Morales Velásquez ${ }^{1} \quad$ Valentina Velásquez Rivera ${ }^{1} \quad$ Walter D. Cardona Maya ${ }^{1}$ \\ ${ }^{1}$ Reproduction Group, Department of Microbiology and Parasitology, \\ School of Medicine, Universidad de Antioquia, Medellín, Colombia \\ Address for correspondence Walter D. Cardona Maya, PhD, Grupo de \\ Reproducción, Departamento de Microbiología y Parasitología, \\ Facultad de Medicina, Universidad de Antioquia, Medellín, Colombia \\ Urol Colomb 2021;30(3):e194-e198. \\ (e-mail:wdario.cardona@udea.edu.co).
}

\author{
Abstract \\ Keywords \\ - sperm \\ - fertility \\ - reproduction \\ - glyphosate \\ - herbicide

\section{Resumen}

\section{Palabras clave \\ - espermatozoides \\ - fertilidad \\ - reproducción \\ - glifosato \\ - herbicida}

Introduction Glyphosate is an herbicide used to eradicate illicit crops; however, its use is controversial due to different health problems associated with it. The present study aims to evaluate the effects of glyphosate on human sperm in vitro.

Methods Twenty-two semen samples from healthy normozoospermic men were included; 11 semen samples were incubated with Panzer (INVESA S.A., Antiquia, Colombia) and 11 with Roundup (Monsanto Company, MO, USA). The changes in motility and viability were observed. Functional seminal parameters were evaluated as well.

Results The samples exposed to glyphosate showed less motility and viability; a decrease in the potential of the mitochondrial membrane was observed, and an increase in the lipoperoxidation of the membrane was evidenced.

Conclusion Based on the present results, we concluded that glyphosate has cytotoxic potential for exposed people and may affect their fertility.

Introducción El glifosato es un herbicida utilizado ampliamente para la erradicación de cultivos ilícitos; sin embargo, su uso es polémico debido a diferentes problemas de salud asociados con él. El objetivo del presente estudio fue evaluar los efectos del glifosato sobre los espermatozoides humanos in vitro.

Métodos Se incluyeron 22 muestras de semen de hombres sanos normozoospérmicos, de las cuales 11 se incubaron con Panzer y 11 con Roundup, y se evaluaron los cambios en la movilidad y la viabilidad espermática, además de valorar los parámetros seminales funcionales.

Resultados Las muestras expuestas al glifosato presentaron una menor movilidad y viabilidad, una disminución en el potencial de la membrana mitocondrial, y un aumento en la lipoperoxidación de la membrana.

Conclusiones El glifosato es potencialmente citotóxico para las personas que estén expuestas, y puede afectar su fertilidad. received

January 21, 2021

accepted

March 10, 2021
DOI https://doi.org/

$10.1055 / \mathrm{s}-0041-1731413$.

ISSN 0120-789X.

e ISSN 2027-0119. (c) 2021. Sociedad Colombiana de Urología. All rights reserved. This is an open access article published by Thieme under the terms of the Creative Commons Attribution-NonDerivative-NonCommercial-License, permitting copying and reproduction so long as the original work is given appropriate credit. Contents may not be used for commercial purposes, or adapted, remixed, transformed or built upon. (https://creativecommons.org/ licenses/by-nc-nd/4.0/)

Thieme Revinter Publicações Ltda., Rua do Matoso 170, Rio de Janeiro, RJ, CEP 20270-135, Brazil 


\section{Introduction}

Glyphosate (N-(phosphomethyl)-glycine) is an herbicide used for agricultural purposes in the eradication of unwanted plants, and, in recent decades, it has been widely used for the elimination of illicit crops, a controversial issue in countries like Colombia, due to the different health problems associated with its use. ${ }^{1-3}$ Since 1984 , pesticides have been used in Colombia to help with the War on Drugs' illicit crops. Due to its high effectiveness and supposed safety for human health, the first to be used on a large scale was glyphosate. ${ }^{4}$ The other two herbicides that had been tested previously were paraquat and triclopyr. ${ }^{5}$ Paraquat was discarded due to the possibility of intoxication in drug users, as it happened in Mexico in the $90 \mathrm{~s}^{6}$ and generating severe adverse effects on the respiratory system. ${ }^{7}$ On the other hand, glyphosate, the active ingredient in Roundup (Monsanto Company, MO, USA) and Panzer (INVESA S.A., Antiquia, Colombia), inhibits the enzyme 5-enolpyruvylshikimate-3phosphatephoshase synthetase, essential in the formation of aromatic amino acids as phenylalanine, tyrosine, and tryptophan in plants. ${ }^{8}$

In 2014, a Brazilian study reported that prolonged exposure of a group of zebrafish to different concentrations of glyphosate caused decreased motility, mitochondrial function, and sperm DNA integrity, changes that affected their fertility. ${ }^{9}$ In rats, glyphosate exposure has been observed to increase the percentage of sperm with abnormal morphology and to decrease the expression of two proteins used as markers of sperm nuclear quality (protamine 1 and histone 1). ${ }^{10}$ Glyphosate has even been reported to increase the reactive oxygen species (ROS). ${ }^{11}$

Additionally, when treating human sperm in vitro with glyphosate at a concentration of $0.36 \mathrm{mg} / \mathrm{L}$, the alteration of progressive motility 1 hour posttreatment was observed, ${ }^{12}$ while the decrease in sperm motility after 1 and 3 hours postincubation and mitochondrial dysfunction 1 hour after treatment were observed after incubating them with glyphosate at a concentration of $1 \mathrm{mg} / \mathrm{L}^{13}$

However, the available information regarding humans' potential exposure and the relation with adverse reproductive effects is insufficient. ${ }^{3,14}$ Therefore, the objective of the present study was to determine the in vitro effect of glyphosate on conventional (motility and viability) and functional (mitochondrial membrane potential, membrane integrity, membrane lipoperoxidation, and reactive oxygen species) parameters in human sperm.

\section{Methods}

\section{Semen Samples}

The present experimental in vitro study included 22 semen samples from healthy individuals with normal seminal parameters (normozoospermic), collected by masturbation in a sterile container after a period of sexual abstinence of 2 to 7 days.

Ethical approval for this study was obtained from the bioethics committee of the school of medicine at Universidad de Antioquia, and all men signed an informed consent form.
Sperm motility and viability $(n=22)$ were quantified for each seminal sample following the guidelines established in the manual for seminal analysis published by World Health Organization in $2010,{ }^{15}$ before and after incubating them with each of the two glyphosate brands-Roundup and Panzer-in vitro $(n=22)$. On the other hand, the effect of glyphosate on mitochondrial membrane potential $(n=3)$, the integrity of the membrane $(n=3)$, membrane lipoperoxidation $(n=3)$, and levels of ROS of human sperm $(n=3)$ were intracellularly quantified.

\section{Direct Incubation of Human Sperm with Glyphosate} Twenty-two semen samples were processed, 11 for each glyphosate brand, and compared with the control (phosphate-buffered saline [PBS]). Sperm parameters were quantified at the initial time ( 0 hours) and 1 hour after incubation. Glyphosate was diluted to a $10 \mathrm{mg} / \mathrm{mL}$ (real concentration of the active ingredient glyphosate $3.6 \mathrm{mg} / \mathrm{mL}$ ), a dose significantly lower than the one that is considered toxic.

Three different concentrations of glyphosate were evaluated in terms motility and viability: $1 \mathrm{mg} / \mathrm{mL}, 0.01 \mathrm{~g} / \mathrm{mL}$ and $0.1 \mathrm{~g} / \mathrm{mL}$. During the functional parameters test, the intermediate concentration $(0.01 \mathrm{~g} / \mathrm{mL})$ was selected.

\section{Mitochondrial Membrane Potential}

Sperm cells, both control and sperm cells plus glyphosate, were incubated with propidium iodide (PI, $0.25 \mathrm{mg} / \mathrm{mL}$, Molecular Probes Inc, Eugene, OR, USA) and 3,3' dihexyloxacarbocyanine (DIOC6, $10 \mathrm{nM}$, Molecular Probes) for 30 minutes; sperm were washed once by centrifuging at $300 \mathrm{~g} / 5$ minutes. The pellet was resuspended in PBS, and the reading was performed by flow cytometry as previously standardized. ${ }^{16-18}$

\section{Membrane Integrity Evaluation}

Following the previously established protocol, sperm were incubated with PI at a final concentration of $0.25 \mathrm{mg} / \mathrm{mL}$ and Sybr $14(1 \mu \mathrm{M}$, LIVE/DEAD Sperm-Viability Kit, Molecular Probes Inc.) for 30 minutes, washed once with PBS, the pellet was resuspended in PBS, and the reading was performed by flow cytometry. ${ }^{16-18}$

\section{Membrane Lipoperoxidation Evaluation}

Sperm were incubated with BODYPI C11 dye (Molecular Probes Inc.) for 30 minutes, washed once with PBS, the pellet was resuspended in PBS, and the reading was performed by flow cytometry. ${ }^{16-18}$

\section{Intracellular ROS Production}

Sperm were incubated with 2, 7 Dichloro-dihydro-fluorescein diacetate (DCFH-DA, $1 \mu \mathrm{M}$, Sigma-Aldrich, St Louis, MO, USA) and PI ( $0.25 \mathrm{mg} / \mathrm{mL})$ for 30 minutes, washed 3 times, the pellet was resuspended in PBS, and the reading was performed by flow cytometry following the previously established protocol. ${ }^{16-18}$

\section{Statistical Analysis}

To compare the semen parameters before and after treatment, the Friedman test was performed. Data were analyzed 
using the Prism 6.0 (GraphPad Software, San Diego, CA, USA) statistical software; statistical significance was defined as $p<0.05$. Numeric values were expressed as the median \pm range (minimum to maximum).

\section{Results}

The concentrations of $0.01 \mathrm{~g} / \mathrm{mL}$ and $0.1 \mathrm{~g} / \mathrm{mL}$ showed a significant decrease in the conventional sperm parameters (motility-total and progressive-and viability) with respect to controls samples, - Table 1, - Figures 1 and 2.

The concentration of 0.01 also showed alterations in the functional parameters of sperm, decreasing mitochondrial membrane potential and viability, thus increasing the number of dead cells and increasing membrane lipoperoxidation, - Table 2. In addition, ROS were affected by glyphosate incubation in Panzer $(0.2 \%-0.01-0.44, p<0.05)$ and Roundup (1\%-0.87-1,2-) when compared to the control samples (55\% -41.3-68,7-).

\section{Discussion}

In the present study, an in vitro evaluation of the effect of glyphosate on human seminal parameters was performed. Taken together, the findings of this study evidence that the initial sperm motility of seminal samples are significantly affected when they are in contact with glyphosate at a concentration of $10 \mathrm{mg} / \mathrm{mL}$, which is consistent with the results previously reported by Anifandis et al., who were the first to evaluate the effects of glyphosate on conventional and functional parameters. ${ }^{12,13}$ Additionally, glyphosate is recognized for its effect on testosterone levels, a hormone that plays an essential role during spermatogenesis, so that it could harm both sperm production and its maturation. ${ }^{19}$ On the other hand, the present work shows that glyphosate affects mitochondrial membrane potential and lipoperoxidation of the membrane. Decreased mitochondrial membrane potential could be associated with loss of motility, with mitochondria being the primary source of energy. ${ }^{20} \mathrm{At}$ the same time, the increase in lipoperoxidation generates

Table 1 Effect of Panzer and Roundup herbicides on functional parameters at time 0 and 1 hour after incubation. A: Panzer, and B: Roundup

\begin{tabular}{|l|l|l|l|l|l|l|l|l|}
\hline A. \\
\hline & Panzer \\
\hline & Time 0 \\
\hline & Control & $1 \mathrm{mg}$ & $0.01 \mathrm{~g}$ & $0.1 \mathrm{~g}$ & \multicolumn{1}{l}{ Control } & $1 \mathrm{mg}$ & $0.01 \mathrm{~g}$ & $0.1 \mathrm{~g}$ \\
\hline & Motility I \\
\hline
\end{tabular}


A)

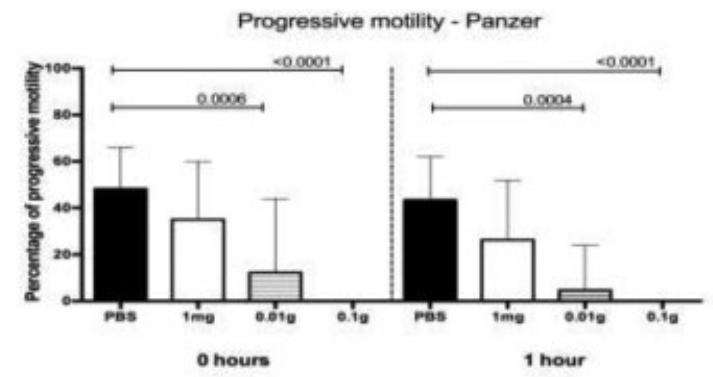

B)

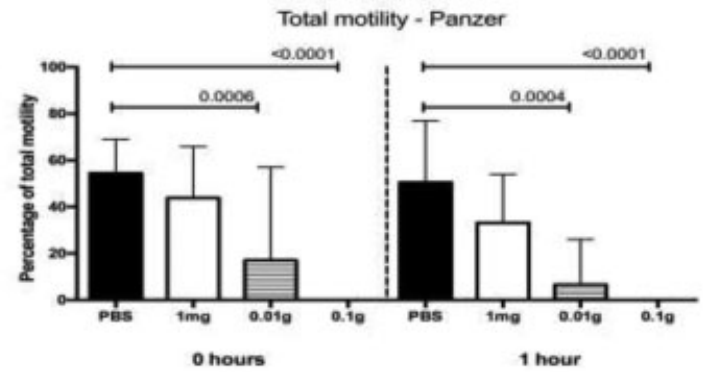

Viability - Panzer

C)

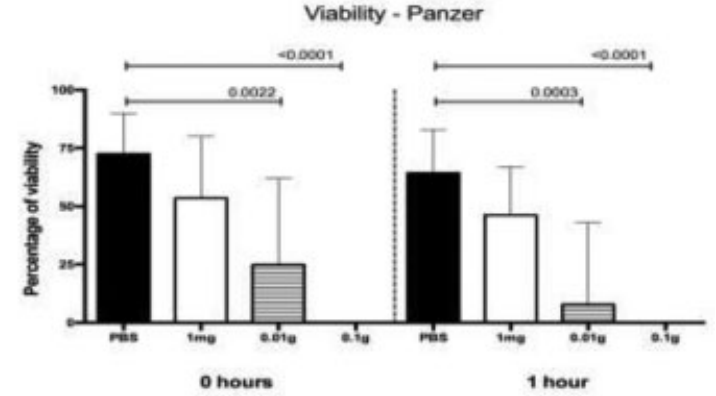

Fig. 1 Effects of Panzer herbicide with glyphosate at different concentrations $(1 \mathrm{mg}, 0.01 \mathrm{~g}$, and $0.1 \mathrm{~g}$ ) on (A) progressive motility (\%), (B) total motility (\%) and (C) sperm viability (\%) respectively to the time of measurement compared with the initial sample in phosphatebuffered saline as a control.

Table 2 Consolidated effect of Panzer and Roundup herbicides $(0.01 \mathrm{~g})$ on functional parameters

\begin{tabular}{|l|l|l|l|}
\hline \multicolumn{4}{|l|}{ High mitochondrial membrane potential (\%) } \\
\hline & Control & Panzer $\mathbf{0 . 0 1} \mathbf{g}$ & $\begin{array}{l}\text { Roundup } \\
\mathbf{0 . 0 1} \mathbf{g}\end{array}$ \\
\hline Median & 46 & 10.9 & 5.5 \\
\hline $\begin{array}{l}\text { Minimun- } \\
\text { Maximun }\end{array}$ & $43.6-48.4$ & $5.6-16.2$ & $15.4-17.5$ \\
\hline Viability (\%) & \multicolumn{5}{|l}{} \\
\hline Median & 60 & 8.1 & 5.1 \\
\hline $\begin{array}{l}\text { Minimun- } \\
\text { Maximun }\end{array}$ & $58.8-61.2$ & $0.06-16.2$ & $4.8-6.1$ \\
\hline Lipoperoxidation (\%) & 17.5 & 17.4 \\
\hline Median & 2.4 & $4.6-33.1$ & $15.3-18.5$ \\
\hline $\begin{array}{l}\text { Minimun- } \\
\text { Maximun }\end{array}$ & $1-4.1$ & & \\
\hline
\end{tabular}

A)

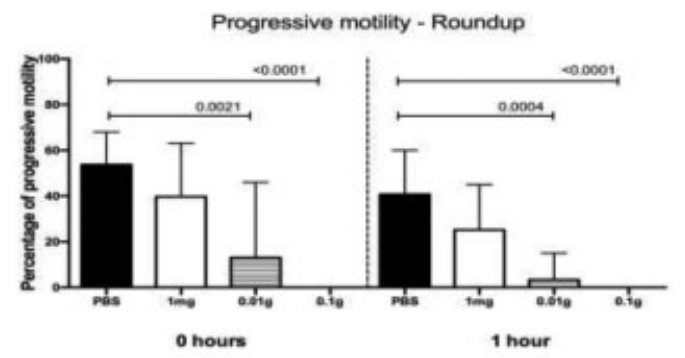

B)

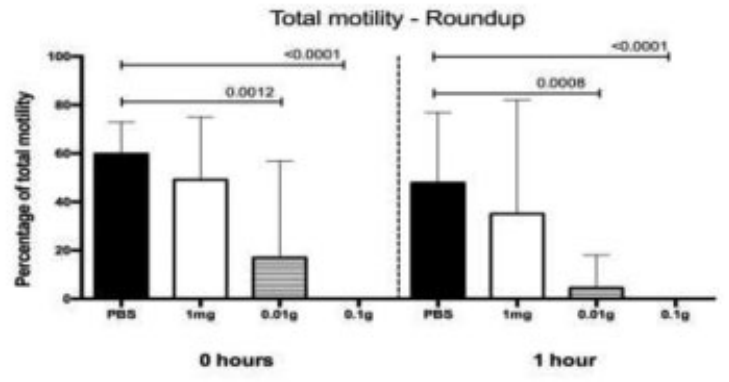

C)

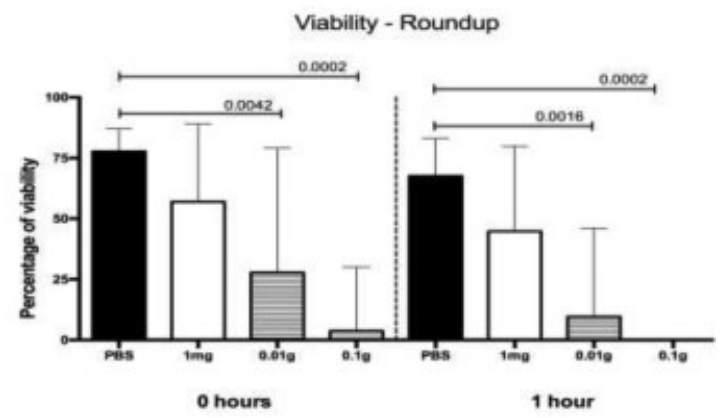

Fig. 2 Effects of Roundup herbicide with glyphosate at different concentrations $(1 \mathrm{mg}, 0.01 \mathrm{~g}$, and $0.1 \mathrm{~g}$ ) on (A) progressive motility (\%), (B) total motility (\%) and (C) sperm viability (\%) respectively to the time of measurement compared with the initial sample in phosphatebuffered saline as a control.

irreversible oxidative damage in male reproductive cells since it leads to a considerable increase in the permeability of cell membrane, making them more susceptible to oxygen free radicals, driving them even to total lysis, which would explain increased dead cells and decreased viability. ${ }^{18}$

On the other hand, studies in different animal models report that glyphosate affects sperm quality. ${ }^{9,21-24}$ Glyphosate has been observed to affect motility, mitochondrial membrane integrity, and DNA integrity in zebrafish, primarily. ${ }^{9}$ When exposed to glyphosate, the testosterone levels, sperm motility, concentration, viability, and epididymal weight of rats were found to be considerably lower. ${ }^{22}$ Furthermore, a study that evaluated the relationship between rabbits and glyphosate resulted in a reduction in body weight, libido, ejaculate volume, sperm concentration, and increased the number of abnormal sperm cells and viability..$^{21}$ Additionally, when evaluating the effect of glyphosate on the seminal parameters of yellow-tailed tetra fish (Astyanax lacustris), a widely used species for human consumption, alteration of motility, concentration, and sperm viability was observed. ${ }^{24}$ Finally, when evaluating the effect of glyphosate exposure in other fish (Jenynsia multidentata), an oxidative 
imbalance was reported due to the increase in oxygen free radicals and a decrease in motility and sperm concentration. $^{23}$

The strengths of our study are that all semen analysesconventional and functional- were performed in the same laboratory, using the same glyphosate dilution and methodology. The limitations of our study include small sample size.

\section{Conclusion}

In conclusion, the present work results allow us to postulate that glyphosate, both Roundup and Panzer, affects the conventional and the functional parameters of human sperm in vitro. Although the negative effect generated by Panzer is slightly lower than that observed with Roundup, both have the cytotoxic potential for people who are exposed and may be affecting their fertility. Finally, additional studies are required to establish the potential role of glyphosate on fertility and human semen parameters in vivo in men exposed to glyphosate.

Conflict of Interests

The authors have no conflict of interests to declare.

\section{References}

1 Camacho A, Mejía D. The health consequences of aerial spraying illicit crops: The case of Colombia. J Health Econ 2017; 54:147-160

2 Campuzano Cortina C, Feijoó Fonnegra LM, Manzur Pineda K, Palacio Muñoz M, Rendón Fonnegra J, Zapata Díaz JP. Efectos de la intoxicacion por glifosato en la poblacion agrícola: revision de tema. Rev CES Salud Pública 2017;8(01):121-133

3 Cardona Maya WD. El glifosato afecta negativamente a los espermatozoides humanos: evidencia in vitro. El glifosato afecta negativamente a los espermatozoides humanos: evidencia in vitro. Urología Colombiana 2020;29(02):96-98

4 Idrovo AJ. De la erradicación de cultivos ilícitos a la erradicación del glifosato en Colombia. Rev Univ Industrial Santander Salud 2015;47(02):113-114

5 Hidrovo AJ. Plaguicidas usados en la fumigación de cultivos ilícitos y salud humana: una cuestión de ciencia o política? Rev Salud Publica (Bogota) 2004;6:199-211

6 Joyce S. Environmental casualties of the war on drugs. Environ Health Perspect 1999;107(02):A74-A77

7 Manktelow BW. The loss of pulmonary surfactant in paraquat poisoning: a model for the study of the respiratory distress syndrome. Br J Exp Pathol 1967;48(03):366-369

8 Gomes MP, Smedbol E, Chalifour A, et al. Alteration of plant physiology by glyphosate and its by-product aminomethylphosphonic acid: an overview. J Exp Bot 2014;65(17):4691-4703

9 Lopes FM, Varela Junior AS, Corcini CD, et al. Effect of glyphosate on the sperm quality of zebrafish Danio rerio. Aquat Toxicol 2014; $155: 322-326$
10 Cassault-Meyer E, Gress S, Séralini GE, Galeraud-Denis I. An acute exposure to glyphosate-based herbicide alters aromatase levels in testis and sperm nuclear quality. Environ Toxicol Pharmacol 2014; 38(01):131-140

11 de Liz Oliveira Cavalli VL, Cattani D, Heinz Rieg CE, et al. Roundup disrupts male reproductive functions by triggering calcium-mediated cell death in rat testis and Sertoli cells. Free Radic Biol Med 2013;65:335-346

12 Anifandis G, Katsanaki K, Lagodonti G, et al. The effect of glyphosate on human sperm motility and sperm DNA fragmentation. Int J Environ Res Public Health 2018;15(06):1117

13 Anifandis G, Amiridis G, Dafopoulos K, et al. The in vitro impact of the herbicide roundup on human sperm motility and sperm mitochondria. Toxics 2017;6(01):2

14 Williams AL, Watson RE, DeSesso JM. Developmental and reproductive outcomes in humans and animals after glyphosate exposure: a critical analysis. J Toxicol Environ Health B Crit Rev 2012; 15(01):39-96

15 World Health Organization. WHO laboratory manual for the examination and processing of human semen Behalf of the World Health Organization by Medical Panamericana2010 . [Available from: https://www.who.int/reproductivehealth/publications/infertility/9789241547789/en/

16 Mayorga Torres JM, Peña B, Cadavid AP, Cardona Maya WD. La importancia clínica del ADN espermático en el análisis seminal cotidiano. Rev Cuba Obstet Ginecol 2015;80:265-268

17 Mayorga-Torres BJ, Camargo M, Agarwal A, du Plessis SS, Cadavid AP, Cardona Maya WD. Influence of ejaculation frequency on seminal parameters. Reprod Biol Endocrinol 2015;13(01):47

18 Mayorga-Torres BJM, Camargo M, Cadavid ÁP, du Plessis SS, Cardona Maya WD. Are oxidative stress markers associated with unexplained male infertility? Andrologia 2017;49(05): e12659

19 Dallegrave E, Mantese FD, Oliveira RT, Andrade AJ, Dalsenter PR, Langeloh A. Pre- and postnatal toxicity of the commercial glyphosate formulation in Wistar rats. Arch Toxicol 2007;81(09): 665-673

20 Kasai T, Ogawa K, Mizuno K, et al. Relationship between sperm mitochondrial membrane potential, sperm motility, and fertility potential. Asian J Androl 2002;4(02):97-103

21 Yousef MI, Salem MH, Ibrahim HZ, Helmi S, Seehy MA, Bertheussen K. Toxic effects of carbofuran and glyphosate on semen characteristics in rabbits. J Environ Sci Health B 1995;30(04): 513-534

22 Abarikwu SO, Akiri OF, Durojaiye MA, Adenike A. Combined effects of repeated administration of Bretmont Wipeout (glyphosate) and Ultrazin (atrazine) on testosterone, oxidative stress and sperm quality of Wistar rats. Toxicol Mech Methods 2015;25(01): $70-80$

23 Sánchez JAA, Varela AS, Corcini CD, et al. Effects of Roundup formulations on biochemical biomarkers and male sperm quality of the livebearing Jenynsia multidentata. Chemosphere 2017; 177:200-210

24 Gonçalves BB, Nascimento NF, Santos MP, Bertolini RM, Yasui GS, Giaquinto PC. Low concentrations of glyphosate-based herbicide cause complete loss of sperm motility of yellowtail tetra fish Astyanax lacustris. J Fish Biol 2018;92(04):1218-1224 